\title{
Plant Growth Promoting Rhizobacteria Enhance the Efficiency of the Combination of Organic and Chemical Fertilisers in Sugarcane
}

\author{
Chanyarat Paungfoo-Lonhienne ${ }^{1,2^{*}}\left(\mathbb{D}\right.$, Nantida Watanarojanaporn ${ }^{3}$, Ratchaniwan Jaemsaeng ${ }^{3}$ \\ ${ }^{1}$ School of Agriculture and Food Sciences, The University of Queensland, Brisbane, Australia \\ ${ }^{2}$ Sustainable Organic Solutions Pty Ltd., Brisbane, Australia \\ ${ }^{3}$ Mitr Phol Sugarcane Research Center Co., Ltd., Phu Khiao, Thailand \\ Email: *chanyarat@uq.edu.au
}

How to cite this paper: Paungfoo-Lonhienne, C. Watanarojanaporn, N. and Jaemsaeng, R. (2020) Plant Growth Promoting Rhizobacteria Enhance the Efficiency of the Combination of Organic and Chemical Fertilisers in Sugarcane. Open Journal of Ecology, 10, 440-444.

https://doi.org/10.4236/oje.2020.107028

Received: June 5, 2020

Accepted: June 27, 2020

Published: June 30, 2020

Copyright $\odot 2020$ by author(s) and Scientific Research Publishing Inc. This work is licensed under the Creative Commons Attribution International License (CC BY 4.0).

http://creativecommons.org/licenses/by/4.0/

\begin{abstract}
Modern agricultural practices involve the extensive use of chemical fertilisers to increase productivity. However less than half of the applied chemical fertiliser nitrogen is used by the target crops, and much of the remaining pollutes air and waterways. Farming systems that sustain productivity while reducing the negative effect on the environment are crucially needed. One avenue is to use plant growth promoting rhizobacteria (PGPR) as bio-fertiliser to reduce the dependency on chemical fertiliser. The potential of PGPR to improve the efficiency of the combination of organic and chemical fertilisers has recently been proposed. Here, we demonstrate that this combination benefits sugarcane grown in field conditions.
\end{abstract}

\section{Keywords}

Nitrogen, Fertiliser, Organic Fertiliser, PGPR, Sugarcane, Agriculture, Plant Nutrition

In current mainstream agricultural practice, more than half of the applied chemical $\mathrm{N}$ fertiliser in cropping systems can be lost to the environment, and this problem has been classified as a pressing global issue [1] [2]. In addition, chemical fertilisers that are currently the primary source of fertilisers rely on limited natural resources such as petroleum, phosphate rock, and potassium salts. The unavoidable depletion of these products will lead to problems for farmers, including interrupted availability and increasing costs.

Organic nutrients have gained much interest in the recent decade for their positive roles in plant nutrition and in generating healthy soils. With the recog- 
nition of the importance of organic nutrients and the detrimental effect of chemical fertilisers when applied in excess, modern agriculture is progressing to reduce the use of chemical fertilisers, compensating it with organic fertilisers. Several studies have shown the beneficial effects that this practice has on soil chemical-biological properties and crop yields [3] [4] [5]. To maximise the efficiency of this system, plant growth promoting rhizobacteria (PGPR) have great potential. For example, the addition of PGPR to soils amended with a mixture of $50 \%$ organic and $50 \%$ chemical $\mathrm{N}$ fertiliser increases the growth of Kikuyu grass (Pennisetum clandestinum), leading to yield similar to $100 \%$ chemical $\mathrm{N}$ fertiliser [6]. Importantly, the presence of PGPR also reduced N loss by $95 \%$ relative to full chemical fertiliser treatment.

To further demonstrate the benefit of using PGPR to support organic and chemical fertilisers mixture in agriculture, we tested this combination on another plant, sugarcane (Saccharum officinarum $x$ spontaneum), in glasshouse and field trials. Sugarcane is a global industrial-scale crop, grown in over 110 countries worldwide, and is one of the most important plants for sugar, biomaterials, and renewable energy production [7].

Sugarcane seedlings were grown in the glasshouse (May 2018) on soils containing two different kinds of fertiliser. The first is "Soil Mate" from MitrPhol Sugar Corporation consisting of a combination (1:2 weight ratio) of chemical fertiliser (N-P-K: 16-16-8) and organic fertiliser (N-P-K: 1-2-2). The second is EcoNPK, an organic-chemical fertiliser (N-P-K: 4-3-3) from Sustainable Organic Solutions Pty Ltd. All treatments received the same $\mathrm{N}$ application rate $(5 \mathrm{~g} \mathrm{~N}$ per pot) in the absence (control) or presence of PGPR (SOS3 from Sustainable Organic Solutions Pty Ltd., patent application number PCT/AU2016/050453) coated on a mineral carrier [8] in an application of $10 \mathrm{~g}\left(10^{8} \mathrm{cells} \cdot \mathrm{g}^{-1}\right)$ per pot (40 Litre). Each pot contained one sugarcane seedling, and each treatment consisted of 12 replicates. Plants were grown for 8.5 months.

We observed that the application of SOS3 PGPR enhances plant growth, sett number, and sugar yield in both fertilisers treatments (Figure 1). In the Soil Mate treatment, PGPR increased the weight by $22 \%$, the sett's number by $13 \%$, and the sucrose yield by $22 \%(P<0.05)$. In the EcoNPK treatment, PGPR increased the weight by $33 \%$, the sett's number by $36 \%$, and the sucrose yield by $32 \%(P<0.05)$.

To validate the glasshouse results, we tested sugarcane in the field following commercial standard practices (April 2019). Sugarcane was grown using two types of fertiliser combination, the first corresponding to Soil Mate (see above), and the second consisting of a mixture of Soil Mate and EcoNPK (1:1 N ratio). In the latter, the addition of $50 \%$ of Soil Mate was necessary to compensate for the low NPK levels in EcoNPK (see above). Compared to most other crops, sugarcane requires high amounts of NPK which could not be practically sustained by EcoNPK alone in large-scale fields. All treatments received the same $\mathrm{N}$ application rate $(57 \mathrm{~kg} \mathrm{~N}$ per hectare), in the absence (control) or presence of $15 \mathrm{~kg}$ of 

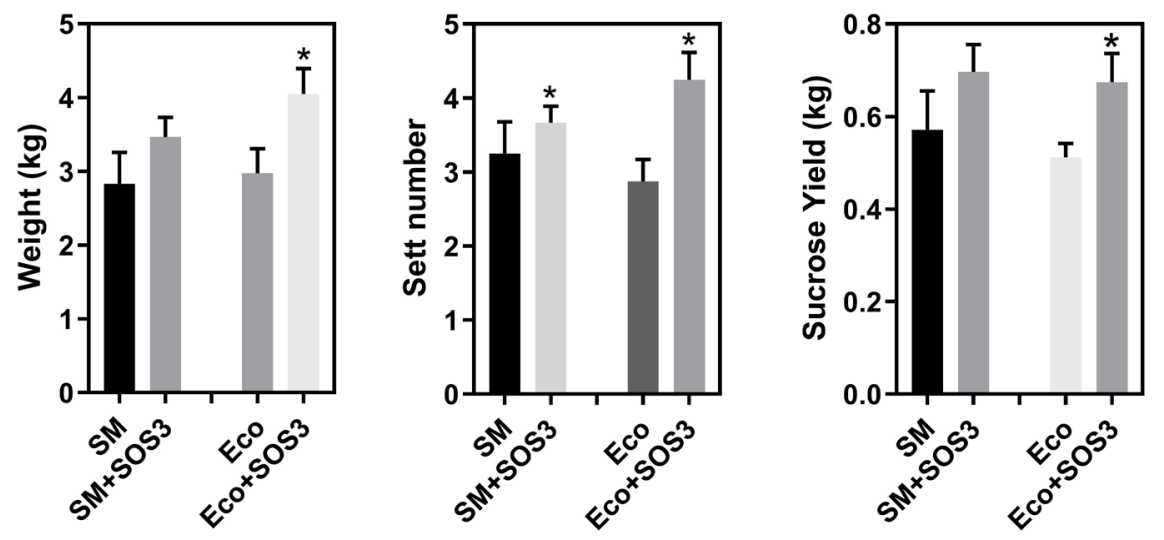

Figure 1. Performance of sugarcane (Saccharum officinarum $x$ spontaneum) grown with the plant growth promoting rhizobacteria (PGPR) strain SOS3 in the glasshouse. Sugarcane was grown for 8.5 months on Soil Mate (SM) or EcoNPK (Eco) organic-chemical mix fertilised soil, in absence or presence of SOS3 PGPR bacterium. Bars represent averages and standard errors of $8-12$ replicates. Asterisks above bars indicate significant differences from the control (no PGPR) $(P<0.05$, Student's t-test).

mineral carrier coated with SOS3 $\left(10^{7}\right.$ cell. $\left.\mathrm{g}^{-1}\right)$. Sugarcane was grown for nine months. The plot size was $6400 \mathrm{~m}^{2}$ ( $1600 \mathrm{~m}^{2}$ for each treatment).

The field trial showed similar results to the glasshouse experiment. The addition of PGPR to the Soil Mate treatment led to an increase of sugarcane $(18 \%, P$ $<0.01)$ and sucrose yield (12\%), and its addition to the 1/2Soil Mate + EcoNPK treatment increased sugarcane and sucrose yields by $13 \%(P<0.5)$ and $17 \%(P<$ 0.5 ), respectively (Figure 2).

Our present study on sugarcane, in accordance with the previous research made on Kikuyu grass [6], strongly suggests that the use of PGPR along with a combination of organic and chemical fertilisers can offer a viable avenue in agriculture. The nutrient use efficiency is the main target of nutrient management to control fertiliser losses [9], which otherwise causes significant economic damage and severely pollutes the environment via leaching, runoff and volatilisation etc. [2] [10] [11]. PGPR appears to be complementary to the use of organic fertilisers, through the enhancement of organic nutrient acquisition and assimilation by the plant [12] [13]. Notably, this combination has also the potential to increase soil health due to the application of organic matter content, which plays a vital role for soil physical, chemical and biological properties [14] [15].

The use of PGPR in sustainable agriculture has received much interest in the past decade due to their beneficial effects such as productions of phytohormones, nitrogen fixation, iron sequestration, phosphorus solubilisation, and alleviation of plant biotic and abiotic stress conditions [12] [13]. However, it's known that the efficacy of PGPR differs widely, with reported benefits ranging from none to considerable. This variability is caused by environmental factors and specific host interactions, limiting its application for agriculture [16] [17].

In conclusion, the addition of PGPR to the combined use of inorganic and 

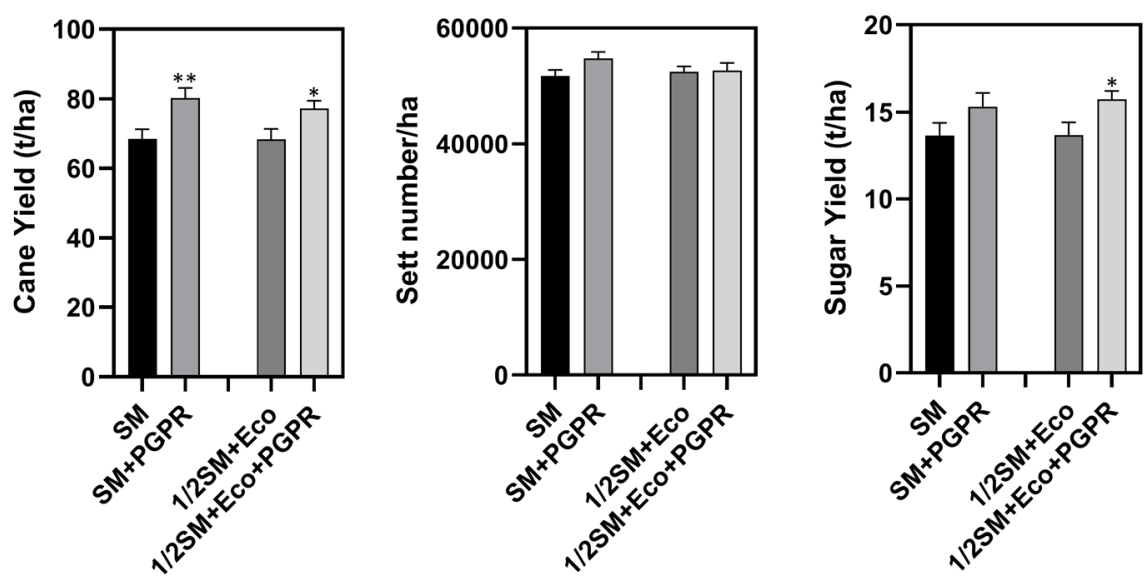

Figure 2. Effect of PGPR on the performance of sugarcane grown in commercial fields. Sugarcane was grown for nine months on Soil Mate (SM) or half SM complemented with EcoNPK (1/2SM + Eco), in the absence (control) or presence of SOS3 bacterium (PGPR). Bars represent averages and standard errors. Asterisks above bars indicate significant differences from the control (no PGPR): ${ }^{\star} P<0.05 ;{ }^{\star \star} P<0.01$ (Student's t-test).

organic has potential implications for agricultural sectors seeking innovative ways to achieve improved nutrient value without harming the environment. The future research needs to verify this system in field measurements at different spatial and temporal scales with different crops. In addition, research should focus on optimising the application techniques to maximise the efficiency of inoculation with PGPR.

\section{Acknowledgements}

We would like to thank Prof. Klanarong Sriroth and Dr Peeraya Klomsa-ard for discussion, Witoon Boonkerd and Anuwat Janlae for assistance with growing and maintaining plants in the glasshouse and the field. This research was funded by Cooperative Research Centres Projects Grant CRCPFIVE000015.

\section{Conflicts of Interest}

The authors declare that they have no known competing financial interests or personal relationships that could have appeared to influence the work reported in this paper.

\section{References}

[1] Gruber, N. and Galloway, J.N. (2008) An Earth-System Perspective of the Global Nitrogen Cycle. Nature, 451, 293-296. https://doi.org/10.1038/nature06592

[2] Rockström, J., Steffen, W., Noone, K., Persson, A., Chapin, F.S., et al. (2009) A Safe Operating Space for Humanity. Nature, 461, 472-475.

https://doi.org/10.1038/461472a

[3] Kaur, K., Kapoor, K.K. and Gupta, A.P. (2005) Impact of Organic Manures with and without Mineral Fertilisers on Soil Chemical and Biological Properties under Tropical Conditions. Journal of Plant Nutrition and Soil Science, 168, 117-122. https://doi.org/10.1002/jpln.200421442 
[4] Chivenge, P., Vanlauwe, B. and Six, J. (2011) Does the Combined Application of Organic and Mineral Nutrient Sources Influence Maise Productivity? A Meta-Analysis. Plant Soil, 342, 1-30. https://doi.org/10.1007/s11104-010-0626-5

[5] Goyal, S., Chander, K., Mundra, M.C. and Kapoor, K.K. (1999) Influence of Inorganic Fertilisers and Organic Amendments on Soil Organic Matter and Soil Microbial Properties under Tropical Conditions. Biology and Fertility of Soils, 29, 196-200. https://doi.org/10.1007/s003740050544

[6] Paungfoo-Lonhienne, C., Redding, M., Pratt, C. and Wang, W. (2019) Plant Growth Promoting Rhizobacteria Increase the Efficiency of Fertilisers While Reducing Nitrogen Loss. Journal of Environmental Management, 233, 337-341. https://doi.org/10.1016/j.jenvman.2018.12.052

[7] Fischer, D., Pfitzner, B., Schmid, M., Simões-Araújo, J.L., Reis, V.M., et al. (2011) Molecular Characterisation of the Diazotrophic Bacterial Community in Uninoculated and Inoculated Field-Grown Sugarcane (Saccharum sp.). Plant Soil, 356, 83-99. https://doi.org/10.1007/s11104-011-0812-0

[8] Berninger, T., Mitter, B. and Preininger, C. (2017) Zeolite-Based, Dry Formulations for Conservation and Practical Application of Paraburkholderia phytofirmans PsJN. Journal of Applied Microbiology, 122, 974-986. https://doi.org/10.1111/jam.13360

[9] Timilsena, Y.P., Adhikari, R., Casey, P., Muster, T., Gill, H. and Adhikari, B. (2015) Enhanced Efficiency Fertilisers: A Review of Formulation and Nutrient Release Patterns. Journal of the Science of Food and Agriculture, 95, 1131-1142. https://doi.org/10.1002/jsfa.6812

[10] Tilman, D., Cassman, K.G., Matson, P.A., Naylor, R. and Polasky, S. (2002) Agricultural Sustainability and Intensive Production Practices. Nature, 418, 671-677. https://doi.org/10.1038/nature01014

[11] Lassaletta, L., Billen, G., Grizzetti, B., Anglade, J. and Garnier, J. (2014) 50 Year Trends in Nitrogen Use Efficiency of World Cropping Systems: The Relationship between Yield and Nitrogen Input to Cropland. Environmental Research Letters, 9, Article ID: 105011. https://doi.org/10.1088/1748-9326/9/10/105011

[12] Calvo, P., Nelson, L. and Kloepper, J.W. (2014) Agricultural Uses of Plant Biostimulants. Plant Soil, 383, 3-41. https://doi.org/10.1007/s11104-014-2131-8

[13] Vessey, J.K. (2003) Plant Growth Promoting Rhizobacteria as Biofertilisers. Plant Soil, 255, 571-586. https://doi.org/10.1023/A:1026037216893

[14] Johnston, A.E., Poulton, P.R. and Coleman, K. (2009) Soil Organic Matter: Its Importance in Sustainable Agriculture and Carbon Dioxide Fluxs. Advances in Agronomy, 101, 1-57. https://doi.org/10.1016/S0065-2113(08)00801-8

[15] Manlay, R.J., Feller, C. and Swift, M.J. (2007) Historical Evolution of Soil Organic Matter Concepts and Their Relationships with the Fertility and Sustainability of Cropping Systems. Agriculture, Ecosystems \& Environment, 119, 217-233. https://doi.org/10.1016/j.agee.2006.07.011

[16] Berg, G., Grube, M., Schloter, M. and Smalla, K. (2014) Unraveling the Plant Microbiome: Looking Back and Future Perspectives. Frontiers in Microbiology, 5, Article 148. https://doi.org/10.3389/fmicb.2014.00148

[17] Figueiredo, M., Seldin, L., Fernando Araujo, F. and Lima Ramos Mariano, Rd. (2011) Plant Growth Promoting Rhizobacteria: Fundamentals and Applications. In: Maheshwari, D.K., Ed., Plant Growth and Health Promoting Bacteria, Springer Berlin, Heidelberg, 21-43. https://doi.org/10.1007/978-3-642-13612-2_2 